\title{
Seedbank Reduction after Different Stale Seedbed Techniques in Organic Agricultural Systems
}

\author{
Stefano Benvenuti*, Mario Macchia \\ Dipartimento di Agronomia e Gestione dell'Agroecosistema, Università di Pisa \\ Via S. Michele degli Scalzi 2, 56124 Pisa, Italy
}

Received: 27 February 2003. Accepted: 4 November 2004.

\begin{abstract}
Little information is available on the stale seedbed effect on seedbank reduction. This weed management is of increasing interest overall in organic agricultural systems where is no possible to use herbicides. The emergence dynamics and related seedbank reduction were evaluated following adoption of two different stale seedbed techniques (with or without irrigation), made during the spring-summer season in 2001 in organic agricultural systems. As expected, emergence was strongly stimulated by irrigation and soil tillage. When the no-tillage technique was adopted (control), the absence of soil disturbance resulted in extremely low emergence levels, associated with a reduction in the number of the relative species. Consequently, analysis of the residual seedbank of the shallow layer (0$10 \mathrm{~cm}$ ) of the control (no-till) showed only small reduction (about 1\%). In contrast, the tillage-only experiment led to a reduction of about $5 \%$ in the same soil layer. However only with the irrigation, a drastic reduction in the amount of seeds (roughly half) was achieved. In particular, grasses showed the highest seedbank reduction rates. Despite this different effectiveness of the stale seedbed techniques, the soil layers at greater depths (10-20 and 20$30 \mathrm{~cm}$ ) were found to be completely unaffected, independently of the agronomic practices carried out. Qualitative analysis of exhumed seeds demonstrated that greatest "forcing of germination" (tillage + irrigation) resulted in a percentage increase of "deep-dormant" seeds as a consequence "non-dormant" seeds decrease. Although stale seedbed appeared to be only partially effective, we believe that if this agrotechnique is properly carried out and repeated at the appropriate times, it promises to be successful in agricultural systems where herbicides are excluded.
\end{abstract}

Key-words: seedbank, seed germination, seedling emergence, preventive weed control, organic agriculture.

\section{Introduction}

Long-term preservation of the agro-ecosystem's potential for weed re-colonization is achieved mainly through accumulation of large quantities of seeds in soil (Roberts and Ricketts, 1979). Except for the few species capable of seedless propagation, the main survival strategy of the most typical weed species is to disseminate an elevated and long-lived (Burnside et al., 1996) quantity of seeds which then accumulate in the various soil layers as a function of tillage practices (Grundy et al., 1996). Such seeds, collectively known as the seedbank, have formed the object of a number of investigations designed to improve knowledge on the basic ecophysiological aspects (Pons, 1991) and to develop practical applications (Hurt and Taylorson, 1986) for preventive control of weed infestation.
In the past few years, this goal has acquired increasing importance in organic agricultural systems where the use of herbicides for weed management is excluded. Thus the pressing need for environment-friendly agriculture has oriented research towards the individuation of non-chemical means for protection of the agroecosystem. The possibility of forcing germination through "stale seedbeds" appears to be one of the most promising strategies, especially when low competitiveness and/or the presence of non-row crops limit the chances for successful "non-chemical" control in post-crop emergence period. However, seed dormancy represents a major impediment to the effectiveness of this weed control technique. Seed dormancy is one of the main survival strategies adopted by weeds in environments where tillage and related agricultural practices periodically disturb

* Corresponding Author: Tel.: +39 050 963571; Fax: +39 050 960330. E-mail address: Sbenve@agr.unipi.it 
the soil and obstruct weed growth and reproduction. It is thus a widespread characteristic of the most common weeds.

The seed dormancy strategy is often characterized by a cyclicity of induction or breaking of dormancy (Baskin and Baskin, 1985) so that germination can be synchronised with periods that best satisfy the plants' heat or photoperiod requirements. Preservation of seeds in the soil is also favoured by the frequent limitations on key germination factors such as temperature (Vleeshouwers, 1997), water (Forcella, 1993), light (Taylorson and Handricks, 1983) and oxygen (Benvenuti and Macchia, 1995). The latter factor is thought to be strongly involved in the germination trigger as a result of aereation created through soil tillage. For example, it is well known that seedbed preparation is followed by seedling emergence flushes (Froud-Williams et al., 1984; Mohler, 1993). Although the physiological bases are not yet fully clarified, this phenomenon clearly suggests that as long as seed remains buried, it is subjected to limited oxygen diffusion, since it is compressed in a soil matrix that impedes the access of oxygen (Pareja and Staniforth, 1985).

Thus the stale seedbed technique consists in loosening the soil in order to achieve an almost optimal gaseous environment around buried seeds and to satisfy the light requirements (just a few flashes of daylight during the breaking up of soil aggregates) considered to be essential for germination of photoblastic seeds (Hartman and Nezadal, 1990). A potential implementation of this agronomic practice could consist in repeated operations of stale seedbeds during the inter-cropping periods (eg. after an autumn-winter cycle crop and prior to sowing the following summer crop), thereby forcing soil seedbank germination. The aim of this study, was to evaluate the seedbank decay rate following two different stale seedbed techniques, with or without irrigation, based on the hypothesis that the soil water potential can represent a strong limiting factor for the effectiveness of this method of preventive weed control.

\section{Materials and methods}

\subsection{General procedure}

Research was conducted in the year 2001 in Sansepolcro (Italy, 43 $36^{\prime}$ North, $10^{\circ} 20^{\prime}$ East) at the Aboca Experimental Farm specialized in production and processing of medicinal herbs exclusively with organic agricultural systems. The experimental area was selected for its consistency of management with to regards agronomic practices (the last 10 years with five-year rotation of chamomile (Matricaria chamomilla L.) - purple coneflower (Echinacea purpurea L., three years) - high mallow (Malva sylvestris L.) managed with the same tillage techniques consisting of ploughing to $30 \mathrm{~cm}$ and rotary hoeing for seedbed preparation), as well as uniformity of pedologic characteristics (USDA classified xerofluvent sandy loam soil, $75 \%$ sand, $18 \%$ lime, $7 \%$ clay; $\mathrm{pH} 7.3,1.5$ organic matter) and floristic composition and quantity of the existing weed communities. Four replicate plots (30 $\mathrm{m} \times 120 \mathrm{~m}$ ) for each treatment (the three below reported seedbed management techniques) were carried out. A randomized block was adopted as experimental design.

The following three stale seedbed management techniques were compared: i) a combination of tillage monthly and irrigation weekly; ii) tillage treatment (roughly once a month) and (iii) a control without tillage or irrigation. In the latter case, crop residues from the last crop (high mallow) were removed from soil. In both of the other two cases, each tillage consisted in rotary hoeing to ensure optimal loosening of the uppermost $10 \mathrm{~cm}$ of soil.

A sprinkler system was used to apply approximately $400 \mathrm{~m}^{3} \mathrm{ha}^{-1}$ for each weekly irrigation. Figure 1 shows the climatic trend during the trial period, which consisted of a typical summer drought with appreciable rainfall only at the beginning and end of the experimental period.

\subsection{Seedbank evaluation and seedling emergence analysis}

As shown in Figure 2, sampling was performed twice, namely before (5 April) and after (20 September) implementation of the agronomic management techniques to the various experimental plots. In each of the 12 plots, 30 soil cores were randomly collected from three different depths $(0-10,10-20$ and $20-30 \mathrm{~cm})$ for each of the 4 replications, for a total of 360 soil samples (120 sampling points) at each dates. Soil cores (4 cm in diameter and $10 \mathrm{~cm}$ long) were taken by means of a metal probe. Following the first sampling date the core sites were georef- 


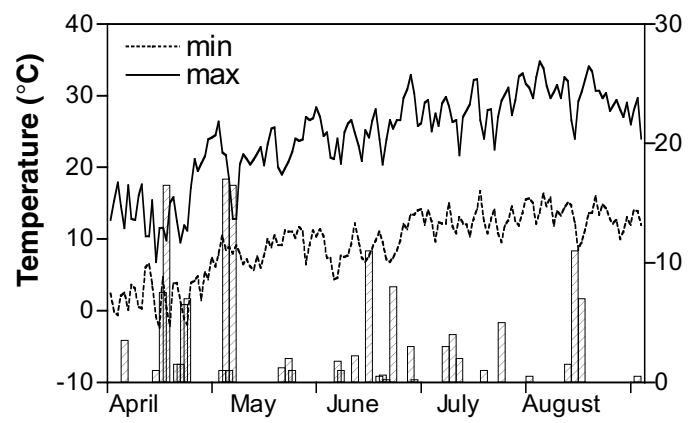

Figure 1. Meteorological data (rainfall, maximum and minimum temperature) of the experimental period (April-September 2001).

erenced so as to carry out subsequent samplings of both seedling emergence and final seedbank, at the same sites, in order to minimize the experimental error resulting from typical patchy weed distribution (Van Groendael., 1988). This mapping of sampling sites was achieved by placing stakes at the sides of the various plots, each stake being labelled with the corresponding orthogonal distance. About 40 days after each of the four soil tillage operations, seedling emergence was monitored and labelled as late spring, early summer, full summer and late summer. Weed seedling were identified within metal frames (30 $\mathrm{cm} \times 30 \mathrm{~cm})$ placed at the centre of the sites $(120$ sampling points) previously selected for soil coring. In the control plots where tillage was not performed, identified seedlings were eradicated manually; thus at each subsequent seedling count, only seedlings that emerged during the preceding interval were considered.

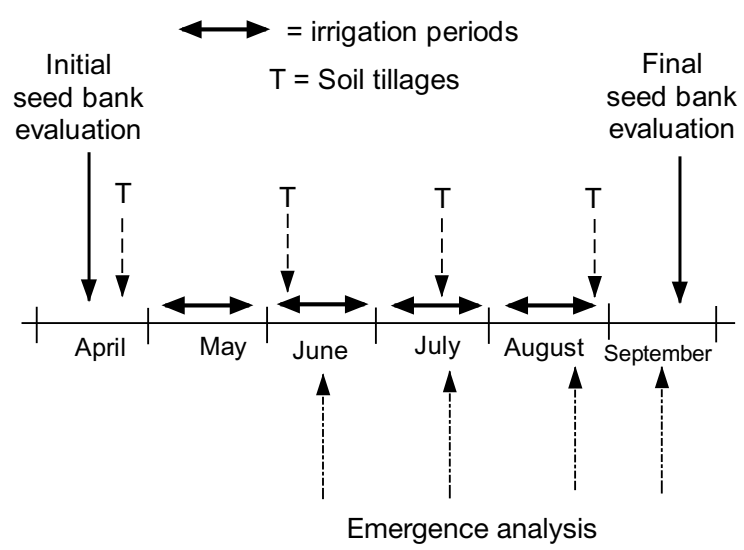

Figure 2. Schematic representation of the agronomic treatments (soil tillage and/or irrigation) and sequence of the experimental evaluations (seedbank and emergence analisys).

\subsection{Seedbank analysis}

Seeds were extracted from cores by pre-treating the soil for approxymately 10 hours in $5 \mathrm{~g}^{-1}$ of sodium hexametaphosphate solution. This resulted in dispersal of the soil colloid matrix, facilitating the subsequent washing phases. Washing was carried out according to a previously adopted methodology (Benvenuti et al., 2001) using a pressure adjustable hydrojet (20-120 bar) to regulate the force of spray, thereby avoiding any possible damage to seed. Soil samples were washed inside metal cylinders $(5 \mathrm{~cm}$ diameter and $50 \mathrm{~cm}$ long) closed on one side by a removable stopper equipped with a fine metallic mesh $(250 \mu \mathrm{m})$. The extracted material (seeds, sand, plant residues, etc.) was separated manually by means of a back-lighted magnifying glass $(8 x)$. Seeds were then identified with the aid of an optical microscope $(45 x)$.

\subsection{Germination test}

Extracted seeds were subjected to germination tests in order to investigate their dormancy and viability characteristics. Seeds were thus placed in Petri dishes equipped with filter paper (Whatmann no. 1) suitably moistened with distilled water, and incubated in climatic cabinets with a photoperiod of 12/12 h. Incubation temperatures were $15 / 20^{\circ} \mathrm{C}$ and $20 / 30^{\circ} \mathrm{C}$ (alternating dark-light) according to the temperature requirements of the species under examination. A light source of about $200 \mu \mathrm{mol} \mathrm{m} \mathrm{m}^{-2} \mathrm{~s}^{-1}$ was obtained from fluorescent tubes (PHILIPS THL 20W/33). Germinated seed count was completed 4 weeks after almost total cessation of germination. Ungerminated seeds underwent chilling treatment $\left(4^{\circ} \mathrm{C}\right.$ in the dark, on moistened filter paper for 1 month) to induce dormancy-breaking, and were then re-incubated under the same conditions previously described. Seeds that germinated following this treatment were classified as light-dormant. Seeds remaining dormant despite this treatment were subjected to the seed-crushing test (Takanagi, 1991) to distinguish viable (deep-dormant) from dead seeds. Four replicates of 100 seeds each were used for each type of exhumed seedbank (with and/or without tillage and irrigation) and repeated twice.

\subsection{Statistical analysis}

After the homogeneity test of variance, arc-sin transformation of percentages relative both to 
seedbank data in the different soil layers and germination data was performed. Seedbank, emergence and germination data were sujected to ANOVA and means were compared by using the Student-Newman-Keuls LSD test $(P<0.05)$.

\section{Results and discussion}

Table 1 shows the size and botanical composition of the seedbank prior to experiments. The seedbank consisted of about 48000 seeds $\mathrm{m}^{-2}$. Although this figure seems elevated as compared to conventional agricultural systems (Forcella and Lindstrom, 1988; Cardina et al., 1991; Ball, 1992; Mulgeta and Stoltenberg, 1997), it is in agreement with findings from similar agricultural systems in which herbicides are not applied (Bond et al., 1998; Benvenuti et al., 2000; Menalled et al., 2001). Overall, 46 species were detected (belonging to 22 different botanic families), although the majority of the seedbank (about $86 \%$ ) consisted of the following 3 species: Amaranthus retroflexus L. (56\%), Portulaca oleracea L. (22\%) and Chenopodium album L. (8\%). Graminaceae (10\%) were substantially represented by the following species: Poa annua L., Echinochloa crus galli L. Beauv., Alopecurus myosuroides Hudson and Lolium multiflorum Lam.

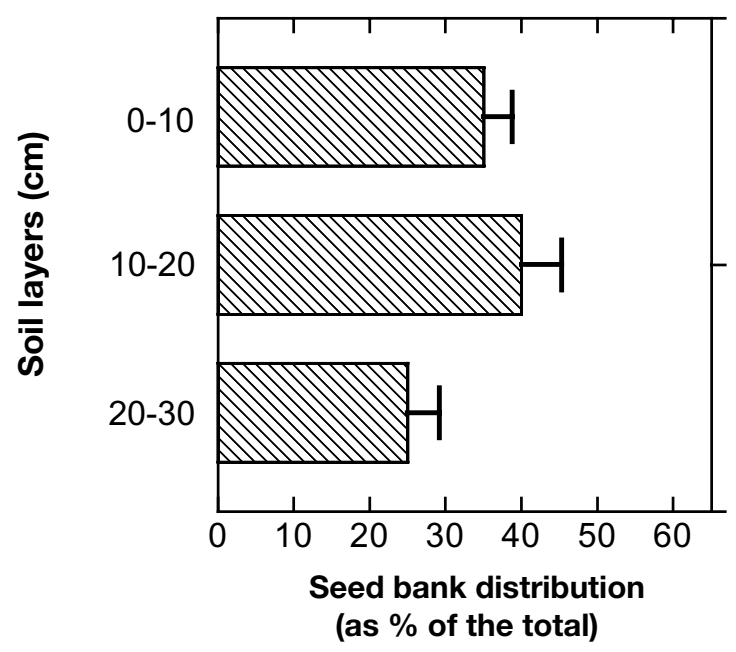

Figure 3. Initial seed bank distribution (as \% of the total). Horizontal bars indicated \pm standard error of the means.

Figure 3 shows the seed distribution in the soil profile prior to the experiment. The layer situated half-way down the ploughed profile $(10-20 \mathrm{~cm})$ was characterized by the highest seed accumulation (40\%), while smaller amounts were found in the shallow layer (about 35\%) and the least amounts in the deep layer. It is well known that although ploughing distributes seeds throughout the ploughed profile, it tends to concentrate the seedbank in the intermedi-
Figure 4. Seedlings emergence $\left(\mathrm{nm}^{-2}\right)$ as a function of the three different treatments (with and/or irrigation and control without any field management) during the experimental period (AprilSeptember 2001). Means followed by the same letter do not differ $(P<0.05)$ at the Student Neumann Keuls (SNK) test.
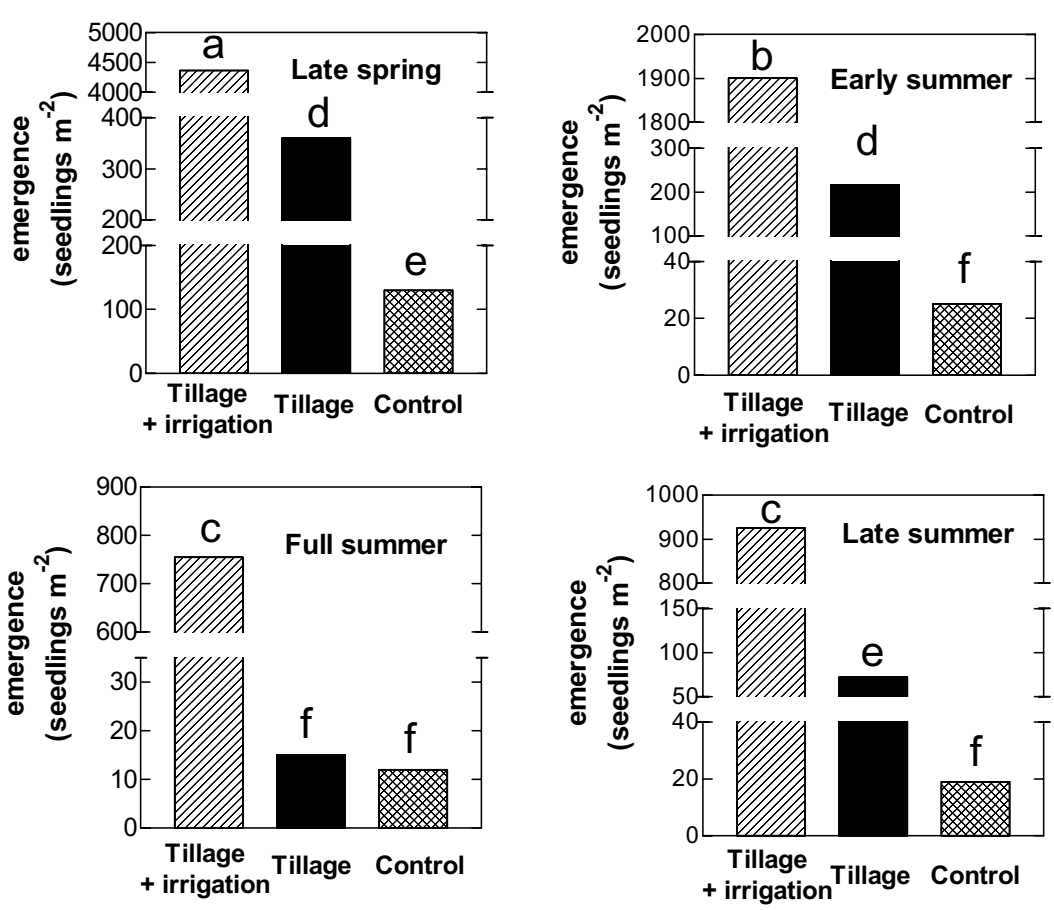
ate layer, because of the partial upturning of soil (Cousens and Moss, 1990).

Soil tillage followed by irrigation gave rise to extremely high and statistically significant seedlings emergence as compared to the other two treatments (Figure 4). During the first sampling period (late spring) the highest seedling emergence counts were detected $(>4000$ seedlings $\mathrm{m}^{-2}$ ). Seedling emergence decreased in the early-summer sampling (though the levels

Table 1. Size and botanical composition of the seed bank (layer 0-30 cm) of the experimental area before of the different managements of stale seedbed.

\begin{tabular}{|c|c|c|c|}
\hline Weed species & $\begin{array}{l}\text { Botanical } \\
\text { family }\end{array}$ & $\begin{array}{l}\text { seeds } \\
\left(\mathrm{nm}^{-2}\right)\end{array}$ & \pm S.E. \\
\hline Agropyrum repens L. Beauv. & graminaceae & 70 & 5.2 \\
\hline Alopecurus myosuroides Hudson & graminaceae & 765 & 31.5 \\
\hline Amaranthus retroflexus L. & amarantaceae & 27160 & 1343.2 \\
\hline Ammi majus L. & apiaceae & 5 & 0.1 \\
\hline Anagallis arvensis L. & primulaceae & 75 & 4.2 \\
\hline Brassica nigra L. Koch & crucifere & 105 & 1.8 \\
\hline Bromus sterilis L. & graminacee & 10 & 1.6 \\
\hline Capsella bursa pastoris L. Medicus & cruciferae & 55 & 3.3 \\
\hline Cerastium holostoides Fries & cruciferae & 70 & 0.8 \\
\hline Chenopodium album L. & chenopodiaceae & 3700 & 345 \\
\hline Cirsium arvense L. Scop & compositae & 15 & 1.5 \\
\hline Convolvolus arvensis $\mathrm{L}$ & convolvolaceae & 5 & 0.3 \\
\hline Cynodon dactylon L. Pers. & graminaceae & 10 & 0.5 \\
\hline Daucus carota L. & apiaceae & 25 & 0.2 \\
\hline Digitaria sanguinalis L. Scop. & graminaceae & 35 & 0.3 \\
\hline Echinochloa crus galli L. Beauv & graminaceae & 1150 & 95.5 \\
\hline Euphorbia helioscopia L. & euphorbiaceae & 55 & 0.3 \\
\hline Fumaria officinalis L. & papaveraceae & 10 & 0.1 \\
\hline Galium aparine $\mathrm{L}$. & rubiaceae & 5 & 0.2 \\
\hline Geranium dissectum $\mathrm{L}$. & geraniaceae & 15 & 0.3 \\
\hline Heliotropium europeum L. & boraginaceae & 5 & 0.2 \\
\hline Lamium purpureum L. & labiatae & 25 & 0.1 \\
\hline Lolium multiflorum Lam. & graminaceae & 220 & 8.6 \\
\hline Malva sylvestris $\mathrm{L}$ & malvaceae & 35 & 0.2 \\
\hline Matricaria chamomilla L. & compositae & 225 & 11.4 \\
\hline Mercurialis annua L. & euphorbiaceae & 25 & 0.1 \\
\hline Myagrum perfoliatum L. & cruciferae & 65 & 0.2 \\
\hline Papaver rhoeas $\mathrm{L}$. & papaveraceae & 15 & 0.1 \\
\hline Plantago lanceolata $\mathrm{L}$. & plantaginaceae & 5 & 1.1 \\
\hline Poa аппиа $\mathrm{L}$. & graminaceae & 1770 & 23.4 \\
\hline Poa trivialis $\mathrm{L}$ & graminaceae & 465 & 0.4 \\
\hline Polygonum aviculare L. & polygonaceae & 45 & 1.8 \\
\hline Polygonum convolvolus L. & polygonaceae & 5 & 0.2 \\
\hline Polygonum laphatifolium L. & polygonaceae & 65 & 7.8 \\
\hline Portulaca oleracea L. & portulacaceae & 10650 & 675.6 \\
\hline Ranunculus arvensis $\mathrm{L}$ & ranuncolaceae & 15 & 0.1 \\
\hline Rumex crispus $\mathrm{L}$. & polygonaceae & 15 & 0.1 \\
\hline Senecio vulgaris $\mathrm{L}$ & compositae & 25 & 1.9 \\
\hline Setaria viridis L. Beauv. & graminaceae & 335 & 2.3 \\
\hline Sinapis arvensis L. & cruciferae & 35 & 0.2 \\
\hline Solanum nigrum L. & solanaceae & 305 & 0.3 \\
\hline Sonchus arvensis L. & compositae & 15 & 1.1 \\
\hline Stellaria media L.Vill. & caryophyllaceae & 110 & 0.5 \\
\hline Taraxacum officinale Weber & compositae & 10 & 0.1 \\
\hline Verbena officinalis L. & verbenaceae & 15 & 2.2 \\
\hline Veronica persica Poiret & scrophulariaceae & 165 & 42.5 \\
\hline Total dicotiledons & & 43075 & 4170 \\
\hline Total grasses & & 4830 & 365 \\
\hline Total weeds & & 47905 & 4053 \\
\hline
\end{tabular}


remained high, roughly 1900 seedlings $\mathrm{m}^{-2}$ and declined to 750 and 900 respectively during the two subsequent samplings. This fall in emergence percentage is likely due to quantitative depletion of seeds in the shallow soil layers as a consequence of germination and emergence phenomena during the previous periods, given that soil tillage operations carried out only on the uppermost soil layer $(10 \mathrm{~cm})$ did not allow deeply buried seeds to move upwards.

As expected, the absence of irrigation after soil tillage operations result in lower emergence rates. Thus although rain occurred during the first and last experimental phase (see Figure 1), in the no-irrigated plots seedling emergence percentages were always significantly $(P<0.05)$ different from irrigated plots. In this case emergences were observed mainly during the first two sampling periods (nearly 400 seedlings $\mathrm{m}^{-2}$ in late spring and 200 in early summer, respectively), decreasing to a few dozen in the subsequent samplings.

In the control treatment in which soil was left virtually undisturbed (without either tillage or irrigation), emergences were extremely low and concentrated in late spring when greater rainfall was recorded. However, the marked differences in emergence rates between the two no-irrigation treatments (except in the full summer sampling, when the almost total absence of rain drastically reduced emergences in both cases) highlighted a close connection between soil ventilation and the induction or inhibition of buried seed germination. This finding is in line with other research (Pareja and Stanford, 1985) showing that seed-soil microsite characteristics are strongly involved in limiting buried seed germination. In particular, it has been noted (Terpstra, 1995) that compaction of soil aggregates plays a crucial role in germination inhibition. Alhough the ecophysiological causes of this phenomenon have not yet been fully clarified, it is probably due to poor soil gas diffusion (Benvenuti and Macchia, 1995). Other studies have shown that in such conditions even phytochrome activation (of photosensitive seeds) by light stimuli becomes ineffective (Benvenuti and Macchia, 1997). On the other hand, the elevated emergence rates observed in the irrigation treatment demonstrate that soil water status constitutes the main factor limiting seedbank germination in the summertime.
Table 2 lists the percentages of seedbank reduction for each of the 46 species detected. The agrotechniques employed to force germination showed a different effectiveness among the various species. Those belonging to the botanical family of poaceae presented the highest germination rates, resulting in greater depletion of the residual seedbank. This was particularly noteworthy in the irrigation treatment, where Poa trivialis, P. annua and Echinochloa crus galli decreased by $75.3 \%, 70.2 \%$ and $69.0 \%$, respectively. This high ratio between real and potential weed flora confirms that grasses tend to accumulate a so-called transitory seedbank (Thompson and Grime, 1979) on account of the fairly low dormancy (Perez et al., 1998) and longevity (Froud-Williams, 1982; Moss, 1985) characteristics of grasses seeds. On the other hand, other species endowed with more pronounced dormancy characteristics showed decidedly limited decreases, as in the case of Matricaria chamomilla, Papaver rhoeas and Veronica persica $(1.5 \%, 2.7 \%$ and $2.8 \%$, respectively). This phenomenon appears to be linked to the ability to acquire secondary dormancy (Baskin and Baskin, 1985), in species whose microthermal requirements would give them little chance of survival in ecologically unsuitable periods.

The data shown in Table 3 confirm a marked reduction in total number of the species emerged during full summer, independently of the agrotechnique adopted. Despite this, irrigation resulted in the smallest decrease of emerged species as compared to the number recorded in late spring (18 and versus 42 species, respectively). It is also worth noting that despite intense forcing of seedbank germination, some species (eg. Fumaria officinalis, Verbena officinalis and Veronica persica) were detected only in the late-summer samplings, suggesting they had by this time lost the secondary dormancy that averted germination during the previous periods when ecological conditions were unsuitable for growth and reproduction of autumn-winter plants. Furthermore, it is important to note that in the treatment without either irrigation or soil tillage, only five species germinated and emerged in full summer: Amaranthus retroflexus, Chenopodium album, Cynodon dactylon, Digitaria sanguinalis and Setaria viridis.

Figure 5 illustrates the final results of seedbank reduction at the end of the trial period. 
Table 2. Seed bank reduction of the several weeds in the shallowest soil layer (0-10). Data are expressed as \% of the initial data. Means followed by the same letter do not differ at $\mathrm{p}<0.05$ according to Student-Newman-Keuls (SNK) test.

\begin{tabular}{|c|c|c|c|c|}
\hline \multirow[t]{2}{*}{ Weed species } & \multirow[t]{2}{*}{$\begin{array}{l}\text { Botanical } \\
\text { family }\end{array}$} & \multicolumn{3}{|c|}{$\begin{array}{l}\text { Seed bank reduction } \\
\text { (as \% of initial data) }\end{array}$} \\
\hline & & Tillage + irrigation & Tillage & Control \\
\hline Agropyrum repens L. Beauv. & graminaceae & $40.2 \mathrm{a}$ & $4.5 b$ & $1.5 \mathrm{c}$ \\
\hline Alopecurus myosuroides Hudson & graminaceae & $37.2 \mathrm{a}$ & $4.2 b$ & $2.1 \mathrm{c}$ \\
\hline Amaranthus retroflexus $\mathrm{L}$. & amarantaceae & $34.2 \mathrm{a}$ & $3.3 b$ & $1.1 \mathrm{c}$ \\
\hline Ammi majus L. & apiaceae & $25.2 \mathrm{a}$ & $2.5 b$ & $0.3 \mathrm{c}$ \\
\hline Anagallis arvensis $\mathrm{L}$. & primulaceae & $19.2 \mathrm{a}$ & $2.7 \mathrm{a}$ & $0.4 \mathrm{c}$ \\
\hline Brassica nigra L. Koch & crucifere & $24.0 \mathrm{a}$ & $3.1 \mathrm{~b}$ & $0.5 \mathrm{c}$ \\
\hline Bromus sterilis L. & graminacee & $14.4 \mathrm{a}$ & $2.2 b$ & $1.5 \mathrm{c}$ \\
\hline Capsella bursa pastoris L. Medicus & cruciferae & $15.2 \mathrm{a}$ & $3.7 b$ & $0.3 \mathrm{c}$ \\
\hline Cerastium holostoides Fries & cruciferae & $5.4 \mathrm{a}$ & $2.3 \mathrm{a}$ & $0.5 b$ \\
\hline Chenopodium album L. & chenopodiaceae & $22.8 \mathrm{a}$ & $3.5 b$ & $0.3 \mathrm{c}$ \\
\hline Cirsium arvense L. Scop & compositae & $16.2 \mathrm{a}$ & $2.4 \mathrm{~b}$ & $0.1 \mathrm{c}$ \\
\hline Convolvolus arvensis $\mathrm{L}$. & convolvolaceae & $19.8 \mathrm{a}$ & $2.9 b$ & $0.2 \mathrm{c}$ \\
\hline Cynodon dactylon L. Pers. & graminaceae & $37.2 \mathrm{a}$ & $4.8 b$ & $0.9 \mathrm{c}$ \\
\hline Daucus carota $\mathrm{L}$. & apiaceae & $18.6 \mathrm{a}$ & $2.7 b$ & $0.2 \mathrm{c}$ \\
\hline Digitaria sanguinalis L. Scop. & graminaceae & $26.4 \mathrm{a}$ & $3.2 b$ & $0.3 \mathrm{c}$ \\
\hline Echinochloa crus galli L. Beauv. & graminaceae & $69.0 \mathrm{a}$ & $4.9 \mathrm{~b}$ & $0.6 \mathrm{c}$ \\
\hline Euphorbia helioscopia L. & euphorbiaceae & $13.5 \mathrm{a}$ & $2.6 b$ & $0.3 \mathrm{c}$ \\
\hline Fumaria officinalis L. & papaveraceae & $10.8 \mathrm{a}$ & $2.1 b$ & $0.1 \mathrm{c}$ \\
\hline Galium aparine L. & rubiaceae & $12.6 \mathrm{a}$ & $2.3 b$ & $0.1 \mathrm{c}$ \\
\hline Geranium dissectum $\mathrm{L}$. & geraniaceae & $11.4 \mathrm{a}$ & $2.2 b$ & $0.1 \mathrm{c}$ \\
\hline Heliotropium europeum L. & boraginaceae & $10.8 \mathrm{a}$ & $1.5 b$ & $0.3 \mathrm{c}$ \\
\hline Lamium purpureum L. & labiatae & $12.6 \mathrm{a}$ & $1.8 \mathrm{~b}$ & $0.2 \mathrm{c}$ \\
\hline Lolium multiflorum Lam. & graminaceae & $22.2 \mathrm{a}$ & $2.6 b$ & $1.2 \mathrm{c}$ \\
\hline Malva sylvestris L. & malvaceae & $10.8 \mathrm{a}$ & $1.1 b$ & $0.2 \mathrm{c}$ \\
\hline Matricaria chamomilla L. & compositae & $1.5 \mathrm{a}$ & $1.2 \mathrm{a}$ & $0.3 b$ \\
\hline Mercurialis annua L. & euphorbiaceae & $10.1 \mathrm{a}$ & $1.2 b$ & $0.2 \mathrm{c}$ \\
\hline Myagrum perfoliatum L. & cruciferae & $18.1 \mathrm{a}$ & $2.3 b$ & $0.3 \mathrm{c}$ \\
\hline Papaver rhoeas $\mathrm{L}$. & papaveraceae & $2.7 \mathrm{a}$ & $3.0 \mathrm{a}$ & $0.2 b$ \\
\hline Plantago lanceolata $\mathrm{L}$. & plantaginaceae & $3.9 \mathrm{a}$ & $1.1 \mathrm{~b}$ & $0.2 \mathrm{c}$ \\
\hline Poa aпnua $\mathrm{L}$. & graminaceae & $70.2 \mathrm{a}$ & $3.7 b$ & $1.1 \mathrm{c}$ \\
\hline Poa trivialis $\mathrm{L}$ & graminaceae & $75.3 \mathrm{a}$ & $4.2 b$ & $1.4 \mathrm{c}$ \\
\hline Polygonum aviculare L. & polygonaceae & $19.9 \mathrm{a}$ & $2.5 b$ & $0.5 \mathrm{c}$ \\
\hline Polygonum convolvolus L. & polygonaceae & $15.4 \mathrm{a}$ & $2.2 \mathrm{~b}$ & $0.2 \mathrm{c}$ \\
\hline Polygonum laphatifolium L. & polygonaceae & $18.0 \mathrm{a}$ & $2.1 b$ & $0.3 \mathrm{c}$ \\
\hline Portulaca oleracea L. & portulacaceae & $30.2 \mathrm{a}$ & $1.8 \mathrm{~b}$ & $0.2 \mathrm{c}$ \\
\hline Ranunculus arvensis $\mathrm{L}$ & ranuncolaceae & $2.2 \mathrm{a}$ & $2.5 \mathrm{a}$ & $0.2 b$ \\
\hline Rumex crispus L. & polygonaceae & $8.5 \mathrm{a}$ & $1.2 b$ & $0.1 \mathrm{c}$ \\
\hline Senecio vulgaris L. & compositae & $11.7 \mathrm{a}$ & $1.6 \mathrm{~b}$ & $0.1 \mathrm{c}$ \\
\hline Setaria viridis L. Beauv. & graminaceae & $27.9 \mathrm{a}$ & $4.8 b$ & $0.9 \mathrm{c}$ \\
\hline Sinapis arvensis L. & cruciferae & $15.2 \mathrm{a}$ & $2.1 b$ & $0.5 \mathrm{c}$ \\
\hline Solanum nigrum $\mathrm{L}$. & solanaceae & $20.9 \mathrm{a}$ & $2.4 \mathrm{~b}$ & $0.3 \mathrm{c}$ \\
\hline Sonchus arvensis L. & compositae & $8.6 \mathrm{a}$ & $0.9 b$ & $0.1 \mathrm{c}$ \\
\hline Stellaria media L. Vill. & caryophyllaceae & $8.5 \mathrm{a}$ & $1.9 \mathrm{~b}$ & $0.2 \mathrm{c}$ \\
\hline Taraxacum officinale Weber & compositae & $6.3 \mathrm{a}$ & $2.9 \mathrm{a}$ & $0.1 b$ \\
\hline Verbena officinalis L. & verbenaceae & $7.9 \mathrm{a}$ & $1.5 b$ & $0.3 \mathrm{c}$ \\
\hline Veronica persica Poiret & scrophulariaceae & $2.8 \mathrm{a}$ & $2.4 \mathrm{a}$ & $0.3 b$ \\
\hline
\end{tabular}

As expected, the most intense management of germination forcing (tillage + irrigation) resulted in the lowest residual seedbank in the shallowest soil layer $(0-10 \mathrm{~cm})$, with number of seeds reduced to about half compared to the initial count. In the same soil profile, tillage without irrigation decreased the initial seed count by less than $5 \%$, showing that water availability was an extremely limiting factor for the germination trigger. However, the concomitant absence of both irrigation and soil tillage gave rise to a seed decrease of only about $1 \%$, showing that the resulting ecological conditions experienced by buried seed (water shortage and lim- 
Table 3. Weed species emerged during the experimental periods in the three different agrothecnics management.

\begin{tabular}{|c|c|c|c|c|c|c|c|c|c|c|c|c|}
\hline & \multicolumn{4}{|c|}{ Tillage + irrigation } & \multicolumn{4}{|c|}{ Tillage } & \multicolumn{4}{|c|}{ Control } \\
\hline & 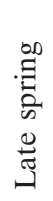 & 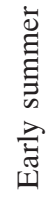 & $\begin{array}{l}\bar{\Xi} \\
\Xi \\
\Xi \\
\Xi \\
\Xi \\
\bar{\Xi} \\
\vec{\Xi}\end{array}$ & 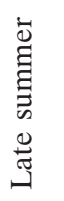 & 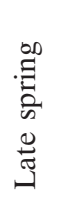 & 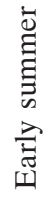 & 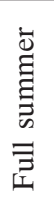 & 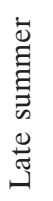 & 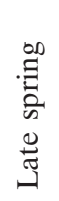 & 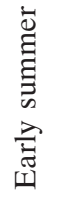 & 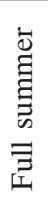 & 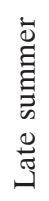 \\
\hline Agropyrum repens L. Beauv. & $\mathrm{x}$ & $\mathrm{x}$ & & & $\mathrm{x}$ & $\mathrm{x}$ & & & $\mathrm{x}$ & & & \\
\hline Alopecurus myosuroides Hudson & $\mathrm{x}$ & $\mathrm{x}$ & & & $\mathrm{x}$ & $\mathrm{x}$ & & & $\mathrm{x}$ & & & \\
\hline Amaranthus retroflexus $\mathrm{L}$. & $\mathrm{x}$ & $\mathrm{x}$ & $\mathrm{x}$ & $\mathrm{x}$ & $\mathrm{x}$ & $\mathrm{x}$ & $\mathrm{x}$ & $\mathrm{x}$ & $\mathrm{x}$ & $\mathrm{x}$ & $\mathrm{x}$ & $\mathrm{x}$ \\
\hline Ammi majus L. & $\mathrm{x}$ & $\mathrm{x}$ & & $\mathrm{x}$ & $\mathrm{x}$ & & & & $\mathrm{x}$ & & & \\
\hline Anagallis arvensis $\mathrm{L}$. & $\mathrm{x}$ & $\mathrm{x}$ & & $\mathrm{x}$ & $\mathrm{x}$ & & & & $\mathrm{x}$ & & & \\
\hline Brassica nigra L. Koch & $\mathrm{x}$ & $\mathrm{x}$ & & $\mathrm{x}$ & $\mathrm{x}$ & $\mathrm{x}$ & & $\mathrm{x}$ & $\mathrm{x}$ & & & \\
\hline Bromus sterilis L. & $\mathrm{x}$ & $\mathrm{x}$ & & $\mathrm{x}$ & $\mathrm{x}$ & $\mathrm{x}$ & & $\mathrm{x}$ & $\mathrm{x}$ & & & \\
\hline Capsella bursa pastoris L. Medicus & $\mathrm{x}$ & $\mathrm{x}$ & & $\mathrm{x}$ & $\mathrm{x}$ & & & $\mathrm{x}$ & $\mathrm{x}$ & & & $\mathrm{x}$ \\
\hline Cerastium holostoides Fries & $\mathrm{x}$ & & & $\mathrm{x}$ & $\mathrm{x}$ & & & $\mathrm{x}$ & $\mathrm{x}$ & & & $\mathrm{x}$ \\
\hline Chenopodium album L. & $\mathrm{x}$ & $\mathrm{x}$ & $\mathrm{x}$ & $\mathrm{x}$ & $\mathrm{x}$ & $\mathrm{x}$ & $\mathrm{x}$ & $\mathrm{x}$ & $\mathrm{x}$ & $\mathrm{x}$ & $\mathrm{x}$ & $\mathrm{x}$ \\
\hline Cirsium arvense L. Scop & $\mathrm{x}$ & & & $\mathrm{x}$ & $\mathrm{x}$ & & & $\mathrm{x}$ & $\mathrm{x}$ & & & $\mathrm{x}$ \\
\hline Convolvolus arvensis L. & $\mathrm{x}$ & $\mathrm{x}$ & & $\mathrm{x}$ & $\mathrm{x}$ & $\mathrm{x}$ & & & $\mathrm{x}$ & & & \\
\hline Cynodon dactylon L. Pers. & $\mathrm{x}$ & $\mathrm{x}$ & $\mathrm{x}$ & $\mathrm{x}$ & $\mathrm{x}$ & $\mathrm{x}$ & $\mathrm{x}$ & & $\mathrm{x}$ & & $\mathrm{x}$ & \\
\hline Daucus carota L. & $\mathrm{x}$ & $\mathrm{x}$ & & $\mathrm{x}$ & $\mathrm{x}$ & & & $\mathrm{x}$ & & $\mathrm{x}$ & & \\
\hline Digitaria sanguinalis L. Scop. & $\mathrm{x}$ & $\mathrm{x}$ & $\mathrm{x}$ & $\mathrm{x}$ & $\mathrm{x}$ & $\mathrm{x}$ & $\mathrm{x}$ & $\mathrm{x}$ & $\mathrm{x}$ & & $\mathrm{x}$ & \\
\hline Echinochloa crus galli L. Beauv. & $\mathrm{x}$ & $\mathrm{x}$ & $\mathrm{x}$ & $\mathrm{x}$ & $\mathrm{x}$ & & & $\mathrm{x}$ & $\mathrm{x}$ & & & $\mathrm{x}$ \\
\hline Euphorbia helioscopia $\mathrm{L}$. & & & $\mathrm{x}$ & $\mathrm{x}$ & & & & $\mathrm{x}$ & & & & $\mathrm{x}$ \\
\hline Fumaria officinalis L. & & & & $\mathrm{x}$ & & & & $\mathrm{x}$ & & & & $\mathrm{x}$ \\
\hline Galium aparine $\mathrm{L}$. & $\mathrm{x}$ & & & $\mathrm{x}$ & $\mathrm{x}$ & & & $\mathrm{x}$ & & & & $\mathrm{x}$ \\
\hline Geranium dissectum $\mathrm{L}$. & $\mathrm{x}$ & & & $\mathrm{x}$ & $\mathrm{x}$ & & & $\mathrm{x}$ & & & & $\mathrm{x}$ \\
\hline Heliotropium europeum L. & $\mathrm{x}$ & & & & $\mathrm{x}$ & & & & $\mathrm{x}$ & & & \\
\hline Lamium purpureum L. & $\mathrm{x}$ & & $\mathrm{x}$ & $\mathrm{x}$ & $\mathrm{x}$ & & & $\mathrm{x}$ & & & & $\mathrm{x}$ \\
\hline Lolium multiflorum Lam. & $\mathrm{x}$ & $\mathrm{x}$ & $\mathrm{x}$ & $\mathrm{x}$ & $\mathrm{x}$ & $\mathrm{x}$ & & & $\mathrm{x}$ & & & \\
\hline Malva sylvestris L. & $\mathrm{x}$ & & & $\mathrm{x}$ & $\mathrm{x}$ & & & $\mathrm{x}$ & & & & $\mathrm{x}$ \\
\hline Matricaria chamomilla L. & $\mathrm{x}$ & $\mathrm{x}$ & & & $\mathrm{x}$ & $\mathrm{x}$ & & & $\mathrm{x}$ & & & \\
\hline Mercurialis annua L. & $\mathrm{x}$ & $\mathrm{x}$ & & $\mathrm{x}$ & $\mathrm{x}$ & & $\mathrm{x}$ & $\mathrm{x}$ & $\mathrm{x}$ & & & $\mathrm{x}$ \\
\hline Myagrum perfoliatum L. & $\mathrm{x}$ & $\mathrm{x}$ & & $\mathrm{x}$ & $\mathrm{x}$ & & & & $\mathrm{x}$ & & & \\
\hline Papaver rhoeas L. & $\mathrm{x}$ & & & $\mathrm{x}$ & $\mathrm{x}$ & & & & $\mathrm{x}$ & & & \\
\hline Plantago lanceolata $\mathrm{L}$. & $\mathrm{x}$ & $\mathrm{x}$ & & & $\mathrm{x}$ & $\mathrm{x}$ & & $\mathrm{x}$ & $\mathrm{x}$ & & & $\mathrm{x}$ \\
\hline Poa aпnиа $\mathrm{L}$. & $\mathrm{x}$ & $\mathrm{x}$ & $\mathrm{x}$ & $\mathrm{x}$ & $\mathrm{x}$ & $\mathrm{x}$ & $\mathrm{x}$ & & & & & \\
\hline Poa trivialis L. & $\mathrm{x}$ & $\mathrm{x}$ & $\mathrm{x}$ & $\mathrm{x}$ & $\mathrm{x}$ & $\mathrm{x}$ & $\mathrm{x}$ & & & & & \\
\hline Polygonum aviculare L. & $\mathrm{x}$ & $\mathrm{x}$ & $\mathrm{x}$ & $\mathrm{x}$ & $\mathrm{x}$ & & & $\mathrm{x}$ & $\mathrm{x}$ & & & \\
\hline Polygonum convolvolus L. & $\mathrm{x}$ & $\mathrm{x}$ & $\mathrm{x}$ & $\mathrm{x}$ & $\mathrm{x}$ & $\mathrm{x}$ & & $\mathrm{x}$ & & $\mathrm{x}$ & & \\
\hline Polygonum laphatifolium L. & $\mathrm{x}$ & $\mathrm{x}$ & $\mathrm{x}$ & $\mathrm{x}$ & $\mathrm{x}$ & $\mathrm{x}$ & & & $\mathrm{x}$ & & & $\mathrm{x}$ \\
\hline Portulaca oleracea L. & $\mathrm{x}$ & $\mathrm{x}$ & $\mathrm{x}$ & $\mathrm{x}$ & $\mathrm{x}$ & $\mathrm{x}$ & & & & $\mathrm{x}$ & & \\
\hline Ranunculus arvensis $\mathrm{L}$ & $\mathrm{x}$ & & & $\mathrm{x}$ & $\mathrm{x}$ & & & & $\mathrm{x}$ & & & \\
\hline Rumex crispus $\mathrm{L}$. & $\mathrm{x}$ & & & $\mathrm{x}$ & $\mathrm{x}$ & & & & $\mathrm{x}$ & & & \\
\hline Senecio vulgaris $\mathrm{L}$ & $\mathrm{x}$ & $\mathrm{x}$ & $\mathrm{x}$ & $\mathrm{x}$ & $\mathrm{x}$ & $\mathrm{x}$ & & & $\mathrm{x}$ & & & \\
\hline Setaria viridis L. Beauv. & $\mathrm{x}$ & $\mathrm{x}$ & $\mathrm{x}$ & $\mathrm{x}$ & $\mathrm{x}$ & $\mathrm{x}$ & $\mathrm{x}$ & $\mathrm{x}$ & & $\mathrm{x}$ & $\mathrm{x}$ & \\
\hline Sinapis arvensis L. & $\mathrm{x}$ & $\mathrm{x}$ & $\mathrm{x}$ & $\mathrm{x}$ & $\mathrm{x}$ & $\mathrm{x}$ & & $\mathrm{x}$ & $\mathrm{x}$ & & & $\mathrm{x}$ \\
\hline Solanum nigrum L. & $\mathrm{x}$ & $\mathrm{x}$ & $\mathrm{x}$ & $\mathrm{x}$ & $\mathrm{x}$ & $\mathrm{x}$ & & & $\mathrm{x}$ & & & \\
\hline Sonchus arvensis L. & $\mathrm{x}$ & $\mathrm{x}$ & & & $\mathrm{x}$ & & & & $\mathrm{x}$ & & & \\
\hline Stellaria media L. Vill. & $\mathrm{x}$ & & & $\mathrm{x}$ & $\mathrm{x}$ & & & & $\mathrm{x}$ & & & $\mathrm{x}$ \\
\hline Taraxacum officinale Weber & $\mathrm{x}$ & $\mathrm{x}$ & & & $\mathrm{x}$ & $\mathrm{x}$ & & & $\mathrm{x}$ & & & \\
\hline Verbena officinalis L. & & & & $\mathrm{x}$ & & & & $\mathrm{x}$ & & & & $\mathrm{x}$ \\
\hline Veronica persica Poiret & & & & $\mathrm{x}$ & & & & $\mathrm{x}$ & & & & $\mathrm{x}$ \\
\hline Emerged weed species & 42 & 31 & 18 & 39 & 42 & 22 & 8 & 24 & 32 & 6 & 5 & 19 \\
\hline
\end{tabular}

ited gaseous exchange in the soil matrix) favours the annual accumulation of seeds. In this respect, it has long been known that the poor ventilation characteristic of undisturbed soil not only inhibits germination but also enhances seed longevity (Roberts and Feast, 1973), while longevity decreases exponentially in soils where more frequent soil disturbance re- 

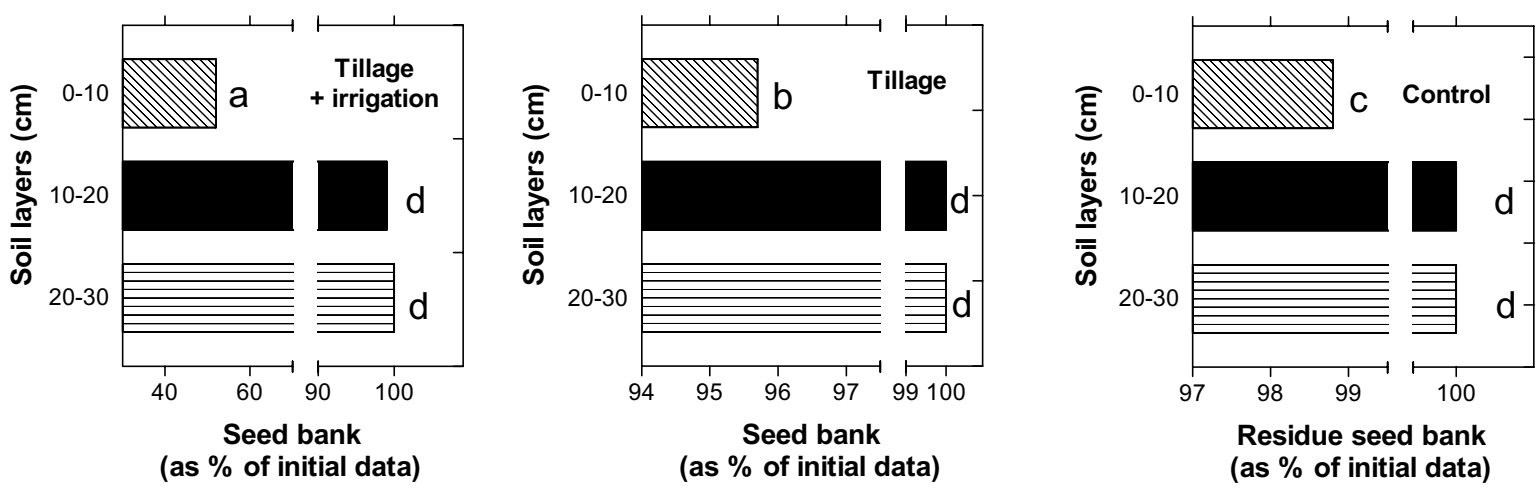

Figure 5. Residue seedbank (as \% of initial data) compared at each of the three different soil layers (0-10, 10-20, and 20$30 \mathrm{~cm}$ ) after the three different treatments (with and/or irrigation and control without any field management). Means followed by the same letter do not differ $(\mathrm{p}<0.05)$ at the Student Neumann Keuls $(\mathrm{SNK})$ test.

sults in greater ventilation (Popay et al., 1994).

Moreover, the desired effect of seedbank reduction was achieved only in the shallowest soil profile $(0-10 \mathrm{~cm})$, given that the seedbank of deeper layers remained unchanged regardless of the agronomic management of the experimental plots. This confirms findings obtained in a controlled environment (Benvenuti et al., 2001), where seedbank germination occurs exclusively in the very first $\mathrm{cm}$ of the shallowest layers, albeit partly as a function of seed size. In other words, below the uppermost soil layers seeds undergo depth-mediated germination inhibition, independently of seed dormancy and agronomic stimuli.

Figure 6 shows dormancy and/or viability of the seedbank exhumed at the end of the trial period. The degree of germination forcing led to a relative increase in dead and dormant (both light and deep dormant) seeds and a decrease in germinable seeds. This was probably due to the fact that non-dormant seeds responded to the germination trigger induced by the agrotechniques, resulting in an increase of seeds characterized by a small (dormant) or impossible (dead seeds) chance of perceiving the trigger. This hypothesis is supported by the finding that the number of deep-dormant seeds increased with increasing input of agrotechniques, while the non-dormant seed percentage was inversely correlated with this parameter.

These results demonstrate that in an environment greatly disturbed by agronomic practices, dormancy plays a crucial role in the vari-
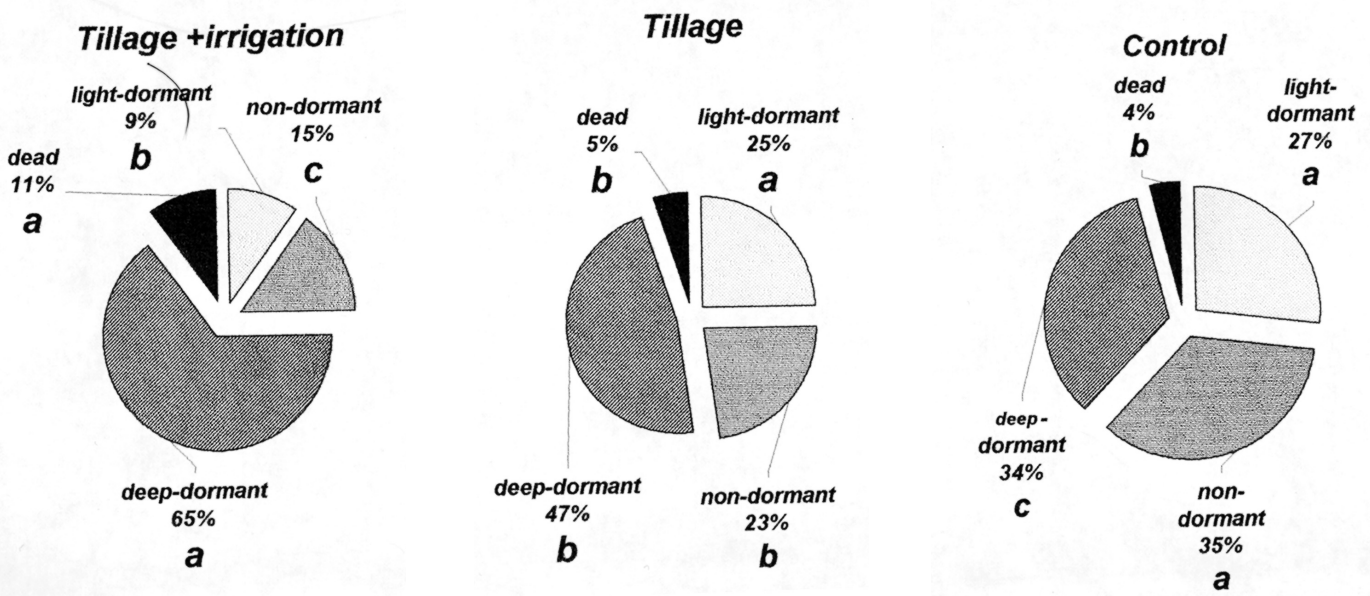

Figure 6. Seed characteristics (germination, dormancy degree, and viability) of the shallowed seedbank $(0-10 \mathrm{~cm})$ after the different agrothecnics (with and/or irrigation and control without any field management). Means followed by the same letter (within the same seed category) do not differ $(\mathrm{p}<0.05)$ at the Student Neumann Keuls (SNK) test. 
ous survival strategies adopted by the different weed species. In effect, dormancy constitutes an important factor of evolution (Mapes et al., 1989), with gradual dormancy-breaking permitting the survival of weed seeds over time in the agro-ecosystem. However, in addition to this important role of endogenous dormancy, depthmediated dormancy in seeds buried below the first $\mathrm{cm}$ of soil must also be taken into account. Thus overall, since seed depletion occurs only in shallow soil layers, it seems advisable that if soil tillage is performed following stale seedbed operations, tillage should carefully avoid upturning the soil layers in order to ensure that seeds characterised by deep dormancy are not transferred closer to the soil surface. In conclusion, the proposed germination forcing of buried weed seeds can be successfully employed not so much as an exclusive non-chemical weapon for weed control but rather as a fundamental agronomic strategy for integrated weed control.

\section{References}

Ball D.A. 1992. Weed seedbank response to tillage, herbicides, and crop rotation sequence. Weed Sci., 40:654-659.

Baskin J.M., Baskin C.C. 1985. The annual dormancy cycle in buried weed seeds: a continuum. Biosci., 35:492498.

Benvenuti S., Macchia M. 1995. Hypoxia effect on buried weed seed germination. Weed Res., 35:343-351.

Benvenuti S., Macchia M. 1997 Phytochrome mediated germination control of Datura stramonium L. seeds. Weed Res., 38:199-205.

Benvenuti S., Silvestri N., Bimbi V., Simonelli G., Macchia M. 2000. Weed seedbank eveluation in some agricultural systems with different environmental impact. In: Proc. XII S.I.R.F.I. Meeting, Milano, 5-6 December, 225-251.

Benvenuti S., Silvestri N., Simonelli G., Macchia M., Bonari E. 2001. Evaluation of seed bank and the relative dynamics of infestation in different management systems for continuous maize cropping. Riv. Agron., 35:23-34.

Benvenuti S., Macchia M., Miele S. 2001. Quantitative analysis of buried weed seedling emergence with increasing soil depth. Weed Sci., 49:528-535.

Bond W., Burston S., Moore H.C., Bevan J.R., Lennartsson M.E.R 1998. Changes in the weed seedbank following different weed control treatments in transplanted bulb onions grown organically and conventionally. Aspects Appl. Biol., 51:273-278.

Burnside, O.C., Wilson R.G., Weisberg S., Hubbard K.G.
1996. Seed longevity of 41 weed species buried 17 years in eastern and Western Nebraska. Weed Sci. 44, 74-86.

Cardina J., Regnier E., Harrison K. 1991. Long-term tillage of seed bank in three Ohio soils. Weed Sci., 39:186-194.

Cousens R., Moss S.R. 1990. A model of the effects of cultivation on the vertical distribution of weed seeds within the soil. Weed Res., 30:61-70.

Forcella F., Lindstrom M.J. 1988. Weed seed population in ridge and conventional tillage. Weed Sci., 36:535503.

Forcella F. 1993. Seedling emergence model for Velvetleaf. Agron. J., 85, 929-933.

Froud-Williams R.J. 1982. A survey of grass weeds in cereal southern England. Weed Res., 22:163-171.

Froud-Williams R.J., Chancellor R.J., Drennan D.S.H. 1984. The effects of seed burial and soil disturbance on emergence and survival of arable weeds in relation to minimal cultivation. J. Appl. Ecol., 21:629-641.

Grundy, A.C., Mead A., Bond W. 1996. Modelling the effect of weed-seed distribution in the soil profile on seedling emergence. Weed Res., 36:375-384.

Hartman K.M., Nezadal W. 1990. Photocontrol of weed without herbicides. Naturwissenshaften, 77:158-163.

Hurt W., Taylorson R.B. 1986. Chemical manipulation of weed emergence. Weed Res., 26:259-267.

Mapes, D.C., Rothwell, G.W., Haworth M.T. 1989. Evolution of seed dormancy. Nature, 337:645-646.

Menalled F.D., Gross K.L., Hammond M. 2001. Weed aboveground and seedbank community responses to agricultural management systems. Ecol. Appl., 11: 1586-1601.

Mohler, C.L. 1993. A model of the effects of tillage on emergence of weed seedlings. Ecol. Appl. 3:53-73.

Moss S.R. 1985. The survival of Alopecurus myosuroides Hugs. seeds in soil. Weed Res., 25:201-211.

Mulgeta D., Stoltenberg D.E. 1997. Seedbank characterization and emergence of a weed community in a plow system. Weed Sci., 45:54-60.

Pareja M.R., Staniforth D.W. 1985. Seed-soil characteristics in relation to weed seed germination, Weed Sci. 33:190-195.

Perez C.J., Waller S.S., Moser L.E., Stubbendieck J.L., Steuter A.A. 1998. Seedbank characteristics of a Nebraska sandhills prairie. J. Range Manag., 51:55-62.

Pons T.L. 1991. Induction of dark dormancy in seeds: its importance for the seed bank in the soil. Funct. Ecol., 5:669-675.

Popay A.I., Cox T.I., Ingle A., Kerr R. 1994. Effects of soil disturbance on weed seedling emergence and its long-term decline. Weed Res., 34:403-412.

Roberts A.H., Feast P.M. 1973. Emergence and longevity of seeds of annual weeds in cultivated and disturbated soil. J. Appl. Ecol., 10:133-137. 
Roberts H.A., Ricketts M.E., 1979. Quantitative relationship between the weed flora after cultivation and the seed population in the soil. Weed Res., 19:269274.

Terpstra, R. 1995. Dormancy of seeds of shepherd's purse in alternating wet and dry, compressed aggregated soil: a laboratory experiment. J. Appl. Ecol., 32:434-444.

Takanagi S., 1991. Quantitative prediction of seasonal patterns of emergence of annual uplands weeds. In: Proc. $3^{\text {th }}$ Tropical Weed Science Conference, 10-12 April, 33-38.

Taylorson R.B., Handricks S.B. 1983. Light control of seed germination. In: Shopshire W., Mohr H. (eds.):
Encyclopedia of Plant Physiology, New Series, 428456. Springer-Verlag, New York. Vol. 16A.

Thompson K., Grime J.P. 1979. Seasonal variation in the seed banks of herbaceus species in ten constrating habitats. J. Ecol., 67:893-897.

Van Groendael R. 1988. Patchy distribution of weeds and some implications for modelling populations dynamics: a short literature review. Weed Res., 28:437441.

Vleeshouwers L.M. 1997. Modelling the effect of temperature, soil penetration resistence, burial depth and seed weight on pre-emergence growth of weeds. Ann. Bot., 79:553-563. 